\title{
EMBRYONIC AND LARVAL DEVELOPMENT OF HALIOTIS TUBERCULATA COCCINEA REEVE: AN INDEXED MICRO-PHOTOGRAPHIC SEQUENCE
}

\author{
G. COURTOIS DE VIÇOSE,* M. P. VIERA, A. BILBAO AND M. S. IZQUIERDO \\ Grupo de Investigación en Acuicultura (GIA) ICCM \& ULPGC P.O. Box 56. 35200 Telde, \\ Las Palmas, Islas Canarias, España
}

\begin{abstract}
First description of the complete embryo and larval development of the Canarian abalone (Haliotis tuberculata coccinea Reeve.) was conducted along 39 stages from fertilization to the appearance of the third tubule on the cephalic tentacles and illustrated in a microphotographic sequence. Eggs obtained by induced spawning with hydrogen peroxide from the GIA captive broodstock were stocked at a density of $10 \mathrm{eggs} / \mathrm{mL}$ and kept at $23 \pm 0.5^{\circ} \mathrm{C}$ for $62 \mathrm{~h}$ until the formation of the third tubule. Live eggs and larvae were continuously observed on a $24 \mathrm{~h}$ basis at a $\times 400$ magnification under transmitted light. At each stages, specific morphological features, illustrated by microscopic photographs, were described, as well as the time required for their apparition. Fertilized eggs diameter was $205 \pm 8 \mu \mathrm{m}$ (mean $\pm \mathrm{SD}$ ), whereas length and width of larvae ready to undergo metamorphosis were $216.6 \pm 5.3 \mu \mathrm{m}$ and $172 \pm 8.8 \mu \mathrm{m}$, respectively. Knowledge on the larval morphological development acquired through this study will contribute to the improvement of larval rearing techniques for this abalone species.
\end{abstract}

KEY WORDS: abalone, embryonic and larval development, Haliotis tuberculata coccinea

\section{INTRODUCTION}

The abalone life cycle includes larval, postlarval, juvenile, and adult stages. Larval development is a gradual process that does not occur in discrete stepwise stages. However, various stages can be recognized during larval development and larval development rate is determined by the time larvae require to show certain distinctive features (Hahn 1989). In Haliotis discus hannai, Ino (1952) identified distinct larval stages with recognizable external features. These morphological features and the order of their appearance in larval developmental stages provided the guidelines for studies of larval development in other abalone species (Oba 1964, Leighton 1974, Seki \& Kan-no 1977, Koike 1978, Owen et al. 1984, Peña 1984; 1986). Hence, larval stage begins with fertilization and is completed with the formation of the fourth tubule on the cephalic tentacles, although larvae are considered ready for settlement when the third tubule appears and larvae starts to explore the surface (Hahn 1989).

Haliotis tuberculata coccinea Reeve; an abalone subspecies present in the Macaronesian Archipielago grows to a maximum size of about $80 \mathrm{~mm}$ in shell length and is considered gourmet seafood in the Canary Islands. During decades this subspecies has been commercially exploited for the local market in the Canary Islands leading to an overexploitation of its stocks, which are presently almost depleted. Therefore, there is a great interest to develop the culture techniques of this species because of its high market value and the interest in recovering its wild populations by restocking. Several studies have been conducted to better understand the physiology of this species and its behavior under captive conditions (Peña 1986, Toledo et al. 2000, Viera et al. 2003, Viera et al. 2005). However, production of seeds remains a major bottleneck for the commercial production of this species, studies related with its embryonic and larval development being scarce and insufficient to allow the

*Corresponding author. E-mail: gtricor@hotmail.com development of larval rearing techniques. Certain stages of the embryonic development of Haliotis tuberculata coccinea were partially described by (Peña 1986) with their respective developmental rates being determined at $15^{\circ} \mathrm{C}$, a temperature out of the natural range, $17-24^{\circ} \mathrm{C}$, for this subspecies. Thus, the present research was conducted to study the complete embryonic and larval development of Haliotis tuberculata coccinea under natural temperature conditions, describing and illustrating for the first time; with photographic support; the morphological features characteristic of each stage and the time required for their apparition.

\section{MATERIAL AND METHODS}

Captive Haliotis tuberculata coccinea broodstock were kept under dark conditions in 60-1 tanks with a flow through system at the Instituto Canario de Ciencias Marinas (Canary Islands, Spain). Water temperature was kept at $23 \pm 0.5^{\circ} \mathrm{C}$ along the experiment, which was carried out during November 2005. Broodstock were fed a mix diet of Ulva rigida, Gracilaria cornea, and Hypnea spinella twice a week. Abalone showing mature gonads in stage 3 (Ebert \& Houk 1984) were transferred to be induced to spawn.

Eight males and 14 females $(58.2 \pm 4.54 \mathrm{~mm}$ and $32.9 \pm$ $8.36 \mathrm{~g}$ ) were placed separately by sex into two 10 -L spawning aquaria filled with $1-\mu \mathrm{m}$ filtered and UV sterilized seawater. They were induced to spawn using the hydrogen peroxide method (Morse et al. 1977). Aquaria were kept in the dark during spawning. Released oocytes were collected in 10-L containers and fertilized, with a final sperm concentration of $10^{5} / \mathrm{mL}$, during $30 \mathrm{~min}$. After that period eggs were rinsed with fresh seawater refills to remove excess sperm and fertilization rates were determined by the proportion of eggs showing dividing cells $1 \mathrm{~h}$ after fertilization. Fertilization rate estimate was performed by taking three $3-\mathrm{mL}$ sample from fertilization containers.

Fertilized eggs were allowed to develop until the trochophore stage in the hatching containers. Trochophore larvae 
were reared at a density of 10 larvae/ml in 70-1 flow-through larval rearing tanks filled with $1 \mu \mathrm{m}$ filtered and UV sterilized seawater.

Observation of embryo and larval development was carried out under transmitted light with a Leitz DMRBE microscope (Leica, Wetzler, Germany) at a magnification of $\times 400$. The study started immediately after fertilization and was continuous for the next $62 \mathrm{~h}$. All observations were performed with pooled larvae in 5-L containers until the appearance of the third tubule on cephalic tentacles. Time required by the larvae to reach each stage was recorded. Pictures were taken with a digital camera (Evolt, E-300, Olympus) attached to the microscope. Egg diameter and larvae's length and width were measured from photographs.

\section{RESULTS}

Spawning was achieved in $2 \mathrm{~h}$ for females whereas it took $1 \mathrm{~h}$ $30 \mathrm{~min}$ for the males. General fertilization rate, recorded one hour after fertilization, during the experiment was $77 \% \pm 3.6 \%$.

Haliotis tuberculata coccinea eggs were dark violet, whereas the larvae showed an orange-yellowish foot, velum, and cephalic tentacles and a violet-colored visceral mass. The average size of unfertilized eggs was $196 \pm 8 \mu \mathrm{m}$. After fertilization, egg size increased up to $205 \pm 8 \mu \mathrm{m}$ and it did not change for the rest of the prehatching period. Length and width of the free swimming trochophore larvae were $166.6 \pm 7.6$ and $124.7 \pm 4.75$, respectively. From the larval shell completion stage until the apparition of the third tubule on the cephalic tentacles larval size was constant with a length of $216.6 \pm 5.3 \mu \mathrm{m}$ and a 102 width of $172 \pm 8.8 \mu \mathrm{m}$.

Thirty-nine distinct, consecutive, larval stages, with recognizable external features, were observed from fertilization until the apparition of the third tubule on the cephalic tentacles. Table 1 shows the time required by eggs and larvae to reach each larval stage at a water temperature of $23 \pm 0.5^{\circ} \mathrm{C}$. Twenty- five min after fertilization (stage 1), the first polar body was discharged (stage 2) followed by the discharge of the second polar body (stage 3) (Fig. 1 A\&B). Cleavage began after discharge of the polar bodies, the first and second one being along the vertical axis of the egg (stages $4 \& 5$ ) and the third in the horizontal plane just above the axis (Fig. 1 C\&D). At the third division, micromeres and macromeres could be differentiated and egg development progressed to the gastrula with cell cleavage being total, unequal and spiral (stages 6-11) (Fig. 2 A to D and Fig. 3 A). At stage 12, cilia grew along the top of the embryo and began beating, causing the rotation of the embryo within the egg membrane (Fig. 3 B). The stomodeum appeared at stage 13 and the prototrochal girdle with its cilia were completely formed during stage 14 (Fig. 3 C\&D). At this stage, the embryo could be identified as a trochophore like larva insitcde the egg. Then, the egg membrane became thinner and larvae started to move more intensively inside the egg, finally bursting the egg membrane with the help of the apical cilia, causing the hatch out and starting to swim (stage 15) (Fig. 4 A).

Swimming trocophora larvae swam in groups forming spirals from the bottom of the container up to the water surface. Soon after hatch-out, the larval shell began to be secreted at the back of the larvae (stage 16) (Fig. 4 B). Larval development continued with the flattening of the apical region and the completion of the velum presenting cilia (stage 17) (Fig. 4 C),
TABLE 1.

Larval development rate of $\boldsymbol{H}$. tuberculata coccinea at $23 \pm 0.5^{\circ} \mathrm{C}$.

\begin{tabular}{|c|c|c|}
\hline Sequence & Larval Development Stage & Time (h) \\
\hline 1 & Fertilization. & 0.00 \\
\hline 2 & Discharge of first polar body. & 0.25 \\
\hline 3 & Discharge of second polar body. & 0.39 \\
\hline 4 & First cleavage ( 2 cells). & 0.49 \\
\hline 5 & Second cleavage ( 4 cells). & 1.26 \\
\hline 6 & Third cleavage ( 8 cells). & 1.32 \\
\hline 7 & Fourth cleavage (12 cells) & 1.55 \\
\hline 8 & Fifth cleavage ( 16 cells). & 2.00 \\
\hline 9 & Morula. & 2.30 \\
\hline 10 & Blastula. & 3.13 \\
\hline 11 & Gastrula. & 4.30 \\
\hline 12 & $\begin{array}{l}\text { Appearance of cilia forming the } \\
\text { prototrochal girdle. }\end{array}$ & 6.21 \\
\hline 13 & Stomodeum. & 7.22 \\
\hline 14 & $\begin{array}{l}\text { Complete formation of prototochal } \\
\text { girdle and cilia. }\end{array}$ & 8.20 \\
\hline 15 & Trochophore larvae ready to hatch out. & 9.11 \\
\hline 16 & Larval shell formation. & 9.35 \\
\hline 17 & $\begin{array}{l}\text { Veliger larvae exhibiting flat apical region } \\
\text { and completely developed velum with cilia. }\end{array}$ & 11.45 \\
\hline 18 & Appearance of larval retractor muscle. & 15.20 \\
\hline 19 & $\begin{array}{l}\text { Appearance of integumental attachment to } \\
\text { larval shell. }\end{array}$ & 15.20 \\
\hline 20 & Development of foot mass. & 15.20 \\
\hline 21 & Appearance of eye spot. & 17.20 \\
\hline 22 & Completion of larval shell. & 18.17 \\
\hline 23 & 90 degree torsion of the cephalo-pedal mass. & 18.38 \\
\hline 24 & 180 degree torsion of cephalo-pedal mass. & 21.29 \\
\hline 25 & $\begin{array}{l}\text { Spines at the end of metapodium and } \\
\text { formation of operculum. }\end{array}$ & 22.38 \\
\hline 26 & Operculum. & 25.00 \\
\hline 27 & Appearance of cilia on foot sole. & 26.29 \\
\hline 28 & Vertical groove formation in velum. & 30.20 \\
\hline 29 & Appearance of propodium. & 36.10 \\
\hline 30 & Appearance of cilia on propodium. & 39.00 \\
\hline 31 & Appearance of cephalic tentacles. & 40.20 \\
\hline 32 & $\begin{array}{l}\text { Appearance of cilia in mantle cavity up } \\
\text { to the anterior edge of the velum. }\end{array}$ & 43.00 \\
\hline 33 & Appearance of apophysis on propodium. & 47.50 \\
\hline 34 & Formation of epipodal tentacles. & 52.32 \\
\hline 35 & Appearance of otolith. & 53.20 \\
\hline 36 & $\begin{array}{l}\text { Appearance of spines on cephalic } \\
\text { tentacles. }\end{array}$ & 54.20 \\
\hline 37 & Protrusion of snout underneath the velum. & 54.40 \\
\hline 38 & $\begin{array}{l}\text { Appearance of two tubules on cephalic } \\
\text { tentacles. }\end{array}$ & 58.05 \\
\hline 39 & $\begin{array}{l}\text { Third tubule appearance on cephalic } \\
\text { tentacles. }\end{array}$ & 61.42 \\
\hline
\end{tabular}

larva being then identified as a veliger. The following steps in larval development consisted in the formation of the retractor muscle (stage 18) and the integumental attachment to the larval shell (stage 19) (Fig. 4 D). During stage 20, the foot mass started to protrude to the top of the shell and the eye spot appeared (stage 21) (Fig. 4 D) followed by the completion of the larval shell, which grew from dorsal to ventral, until covering the body just below the velum (stage 22) (Fig. 5 A). During torsion, the cephalo-pedal mass first rotated $90^{\circ}$ (stage 23) (Fig. 5 A), 

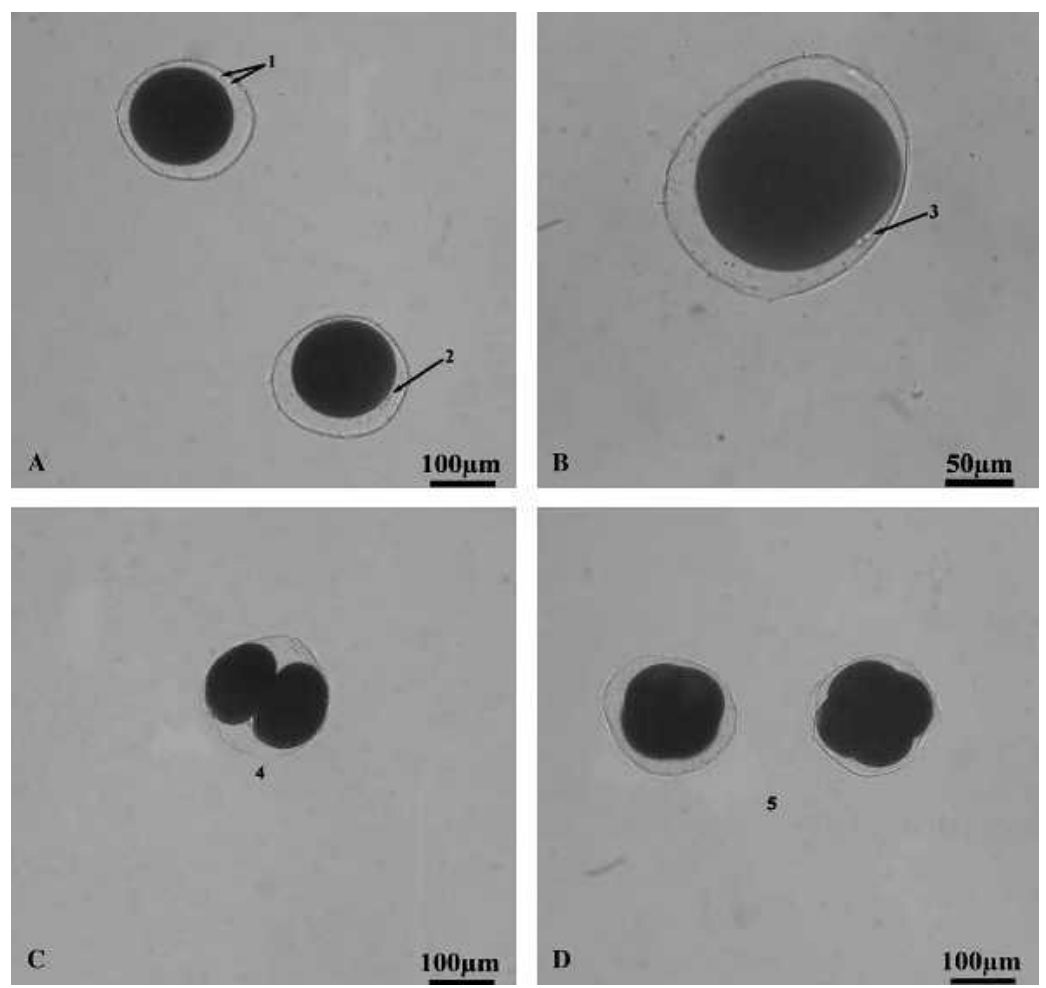

Figure 1. (A) Stage 1, Spermatozoids; Stage 2, discharge of first polar body. (B) Stage 3, discharge of second polar body. (C) Stage 4, first cleavage ( 2 cells). (D) Stage 5, second cleavage (4 cells).

followed by the rotation of the region to become mouth and foot, until finally reaching a $180^{\circ}$ rotation from its original position (stage 24) (Fig. 5 B). After torsion, spines could be observed at the end of the metapodium (stage 25) as well as a developed operculum (stage 26) (Fig. 5 C). At that moment, the cephalo-pedal mass could be retracted into the shell that would be closed by the operculum. In succession, fine cilia developed on the foot sole and began beating (stage 27) (Fig. 5 D), a
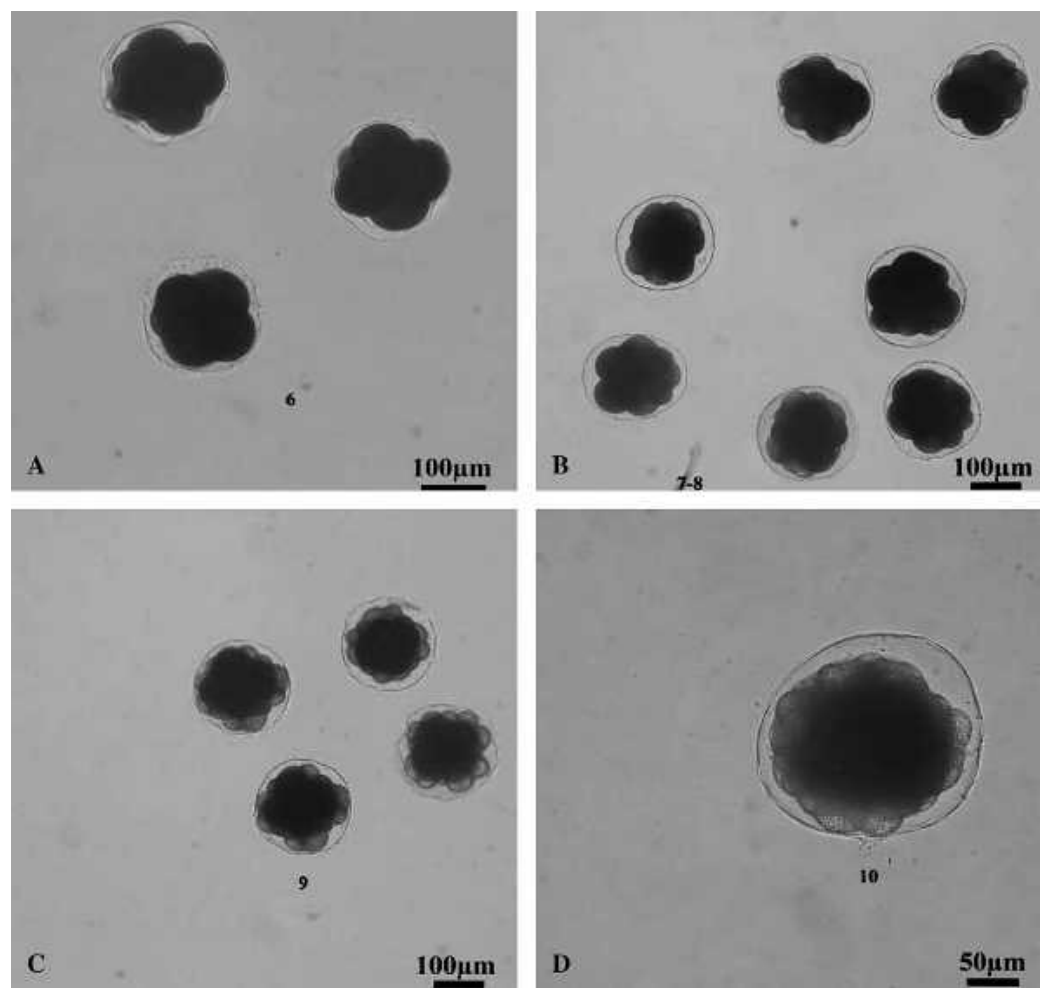

Figure 2. (A) Stage 6, third cleavage (8 cells). (B) Stages 7 and 8, fourth and fifth cleavages (12-16 cells). (C) Stage 9, Morula. (D) Stage 10, Blastula. 

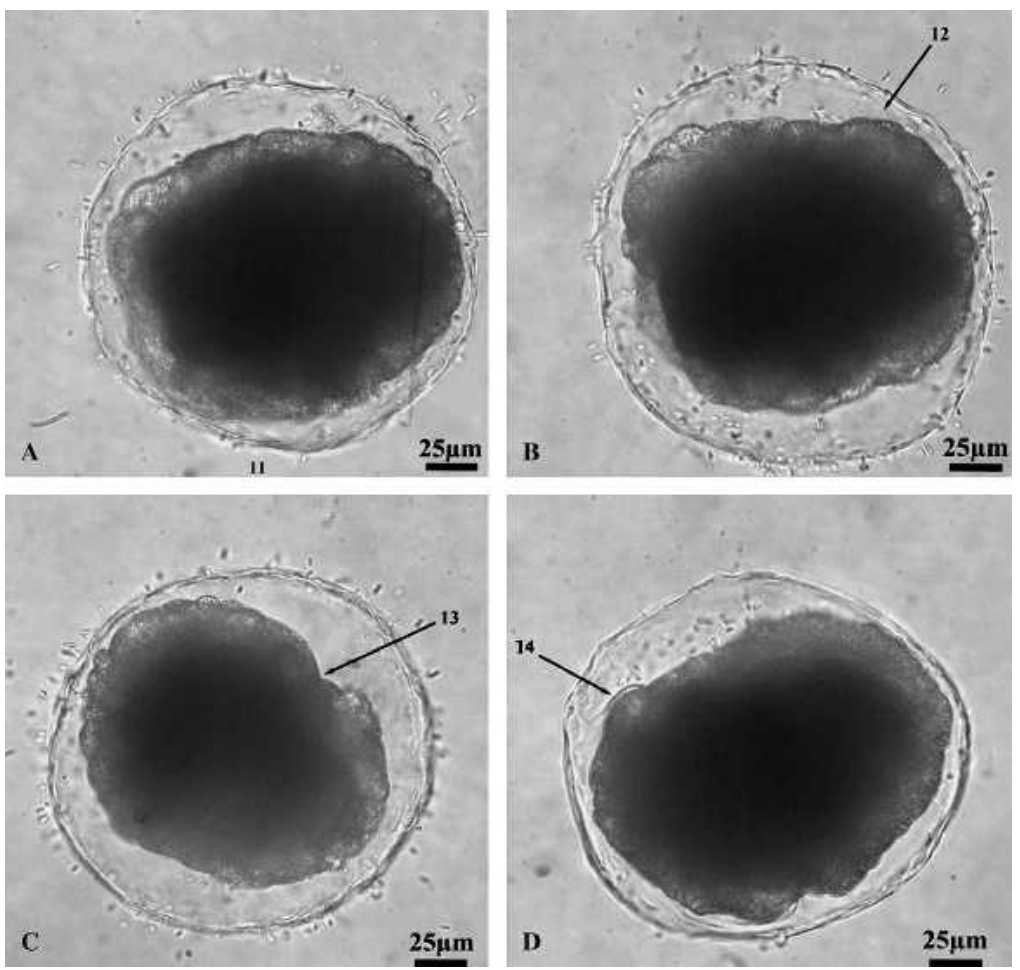

Figure 3. (A) Stage 11, gastrula. (B) Stages 12, appearance of cilia forming the prototrochal girdle. (C) Stage 13, stomodeum. (D) Stage 14, complete formation of prototochal girdle and cilia.

groove appeared in the velum (stage 28), the propodium got formed (stage 29) with cilia growing on it (stage 30), and a cephalic tentacle developed on the velum (stage 31) (Fig. 6
A\&B). Cilia appeared in the mantle cavity and began beating (stage 32) (Fig. $6 \mathrm{C}$ ). Apophysis could be observed on the propodium (stage 33) (Fig. 6 D) and a pair of epipodal tentacles
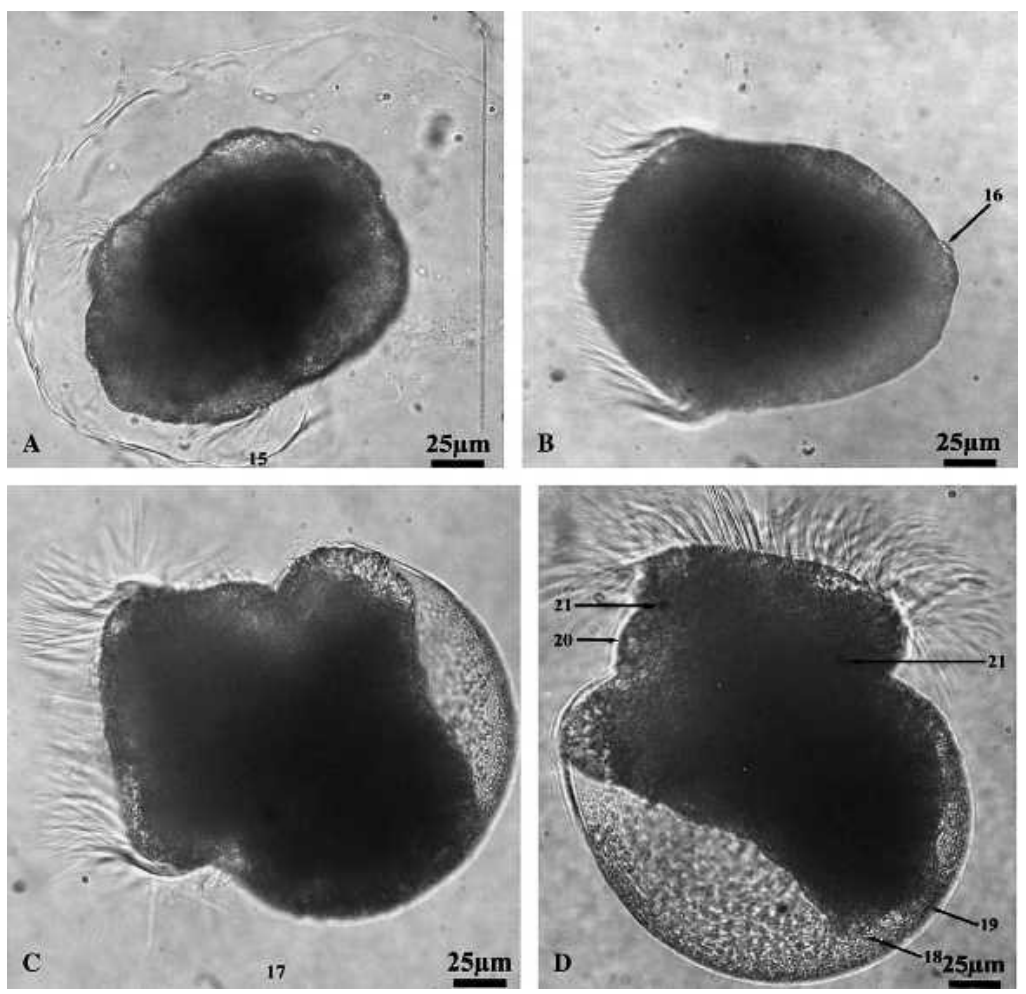

Figure 4. (A) Stage 15, trochophore larvae ready to hatch out. (B) Stages 16, larval shell formation. (C) Stage 17, veliger larvae exhibiting flat apical region and completely developed velum with cilia. (D) Stage 18, appearance of larval retractor muscle. Stage 19, appearance of integumental attachment to larval shell. Stage 20, development of foot mass. Stage 21, appearance of eye spot. 

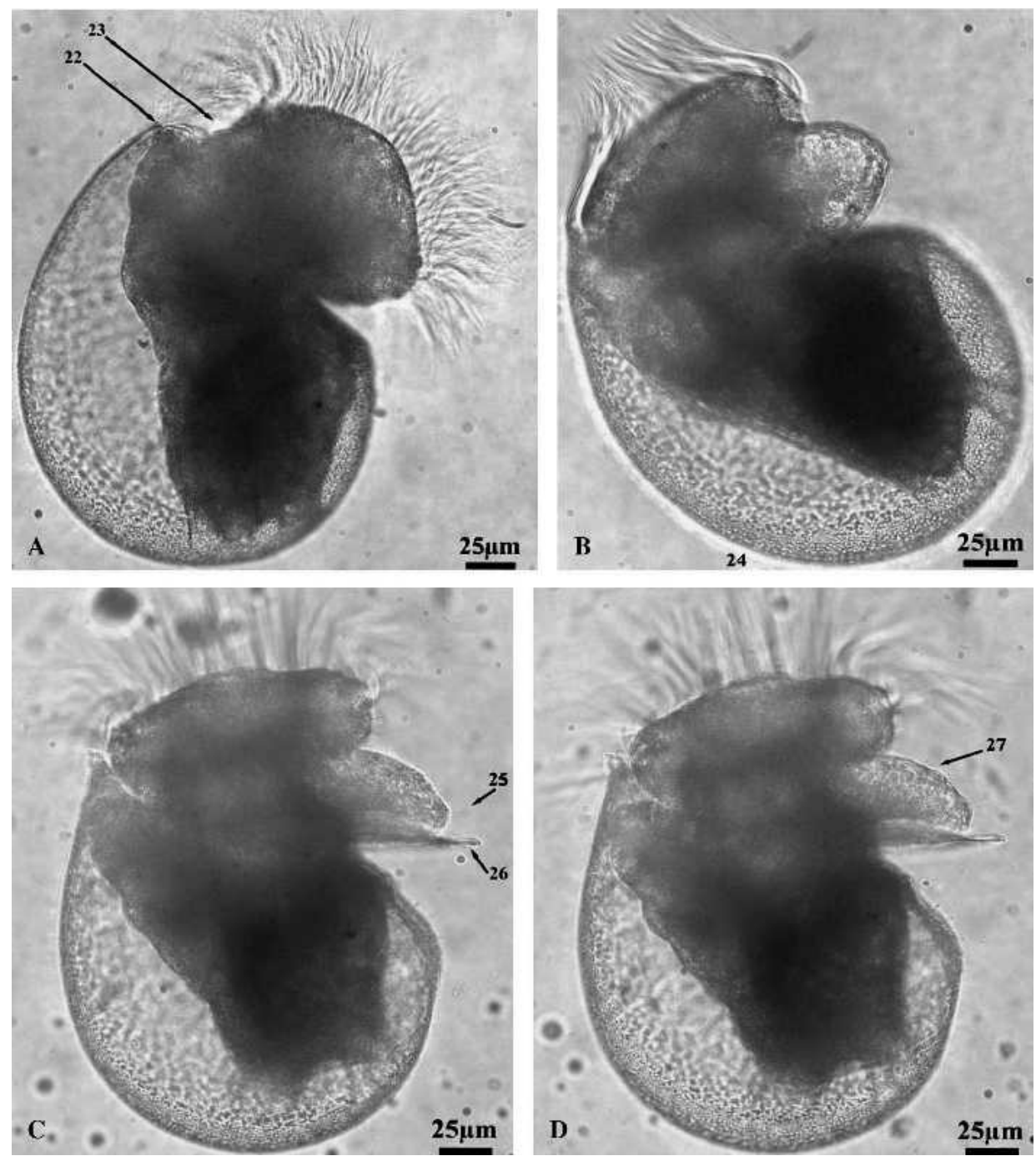

Figure 5. (A) Stage 22, completion of larval shell. Stage 23, 90-degree torsion of the cephalo-pedal mass. (B) Stage 24, 180-degree torsion of cephalopedal mass. (C) Stage 25, spines at the end of metapodium and formation of operculum. Stage 26, operculum. (D) Stage 27, appearance of cilia on foot sole.

formed on both side of the foot (stage 34) (Fig. 7 A). From this point larvae started exploring the surface with their foot but did not stop their swimming behavior considering they had not shed their velum, no suitable settlement substrate being present. The otolith appeared (stage 35), then short spines appeared on the cephalic tentacles (stage 36), followed by the snout protrusion from underneath the velum (stage 37) (Fig. 7 B to D). Two tubules appeared on the cephalic tentacles (stage 38) followed by the apparition of a third tubule on the cephalic tentacles (stage 39) (Fig. 8 A\&B).

\section{DISCUSSION}

The time required by $H$. tuberculata coccinea to start spawning in this study is in agreement with those observed by Peña (1986). Eggs and larvae colors reported among abalone species vary among species of Haliotis genus. For instance $H$. rufescens, $H$. cracherodii, $H$ walallensis, $H$. assimilis, and $H$. kamtschatkana have dark green eggs and green larvae, whereas $H$. fulgens, $H$. sorenseni, and $H$. corrugate produce brown, beige, and olive eggs, respectively; and larvae color reflect those egg pigments (Hahn 1989). Pigmentation of $H$. tuberculata coccinea eggs was dark violet as stated by Peña (1986). However, the colors described by Peña (1986) for trochophore and veliger larvae, violet-colored foot, velum and cephalic tentacles and an orange-yellowish-colored visceral mass, are opposite to the ones observed in the present study.

Size of fertilized abalone eggs also varies from species to species. Diameter of $H$. tuberculata coccinea eggs observed in this study $(205 \pm 8 \mu \mathrm{m})$ was nearly the double of the one found by (Peña, (1986) (102.8 \pm 0.82$)$ for the same abalone species but similar to the one of H. rubra $(200 \mu \mathrm{m})$ (Harrison \& Grant 1971), H. sorenseni $(200 \mu \mathrm{m})$ (Leighton 1972), and H. tuberculata $(210$ $\mu \mathrm{m})$ (Koike 1978). The size of trochophore and veliger also varies depending on the abalone species. The length and width of $H$. tuberculata coccinea larvae, found varied from the ones reported in the literature for other species, and were also different from the ones reported by Peña, (1986) who observed $201 \times 160 \mu \mathrm{m}$ trochophore larvae and $264 \times 206-\mu \mathrm{m}$ larvae having completed their larval shell. These differences could be attributed to distinct 

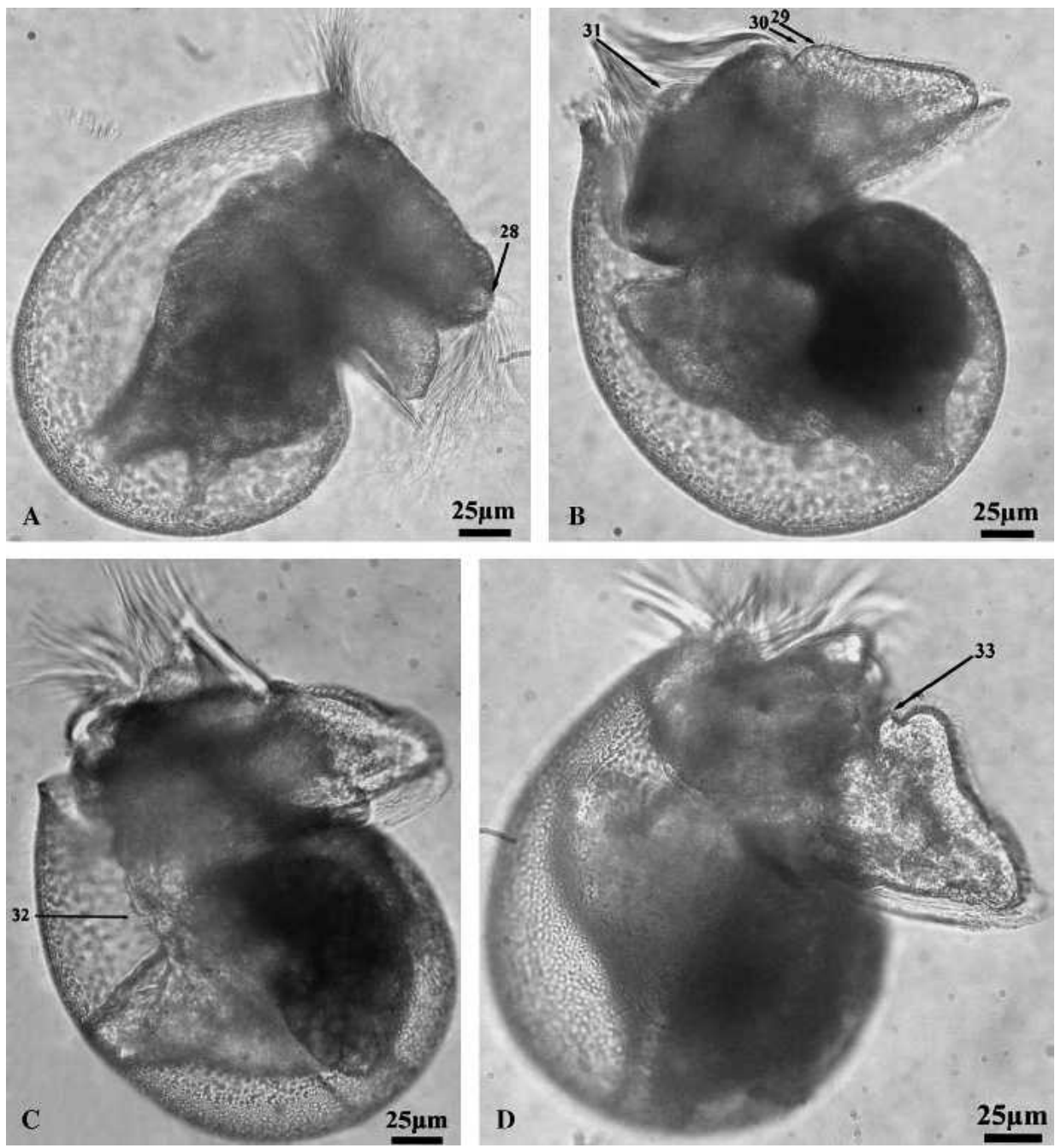

Figure 6. (A) Stage 28, vertical groove formation in velum. (B) Stage 29, appearance of propodium. Stage 30, appearance of cilia on propodium. Stage 31, appearance of cephalic tentacles. (C) Stage 32, appearance of cilia in mantle cavity up to the anterior edge of the velum. (D) Stage 33, appearance of apophysis on propodium.

broodstock feeding and conditioning temperatures as well as dissimilarities in broodstock size and age.

Previous studies on larval development of $H$. discus hannai (Seki \& Kan-no 1977), H. sieboldii, H. discus (Ino 1952) and $H$. diversicolor supertexta (Oba 1964) showed that there were no differences in the development from fertilization to trochophore larvae, between these species. In this study we could confirm this statement, no differences in the development to the trochophore larvae having been observed in $H$. tuberculata coccinea comparing to the rest of the species. However from the trochophore larvae onward, differences were noticed.

Larval development of $H$. tuberculata coccinea, from trochophore stage to torsion differs to that of other species because the formation of the larval retractor muscle, the integumental attachment, and the development of the foot mass occurred simultaneously in the present species. Moreover the apparition of the eye spot was observed before torsion, earlier in the development in comparison with all the other abalone species. However like in $H$. discus hannai, H. sieboldii, $H$. discus, and $H$. diversicolor supertexta, the development of the operculum occurred in $H$. tuberculata coccinea after these stages.
Many differences were noted from torsion to metamorphosis. As in $H$. discus hannai and $H$. asinina (Sawatpeera et al. 2001), larval shell of $H$. tuberculata coccinea was completed before torsion occurred. Conversely in H. sieboldii Ino (1952) found that torsion occurred before larval shell completion. In $H$. tuberculata coccinea, similarly to $H$. asinina, cilia in the mantle cavity were seen after the formation of the first epipodal tentacle whereas the contrary was observed in $H$. discus hannai and the first epipodal tentacle could only be observed after metamorphosis in $H$. gigantea.

Otolith could be observed after the formation of the first epipodal tentacle contrary to the reverse order reported in $H$. tuberculata. Seki and Kan-no (1977) found that snout protrusion and ciliary process on the roof of the mantle cavity happened before the formation of the third tubule on the cephalic tentacles. In agreement with their finding this study confirm a similar order of appearance in $H$. tuberculata coccinea as opposed to Sawatpeera, et al. (2001) who found that they form after the apparition of the third tubule on the cephalic tentacles in $H$. asinina. In $H$. tuberculata ciliary process on the roof of the mantle cavity could only be observed after metamorphosis. 

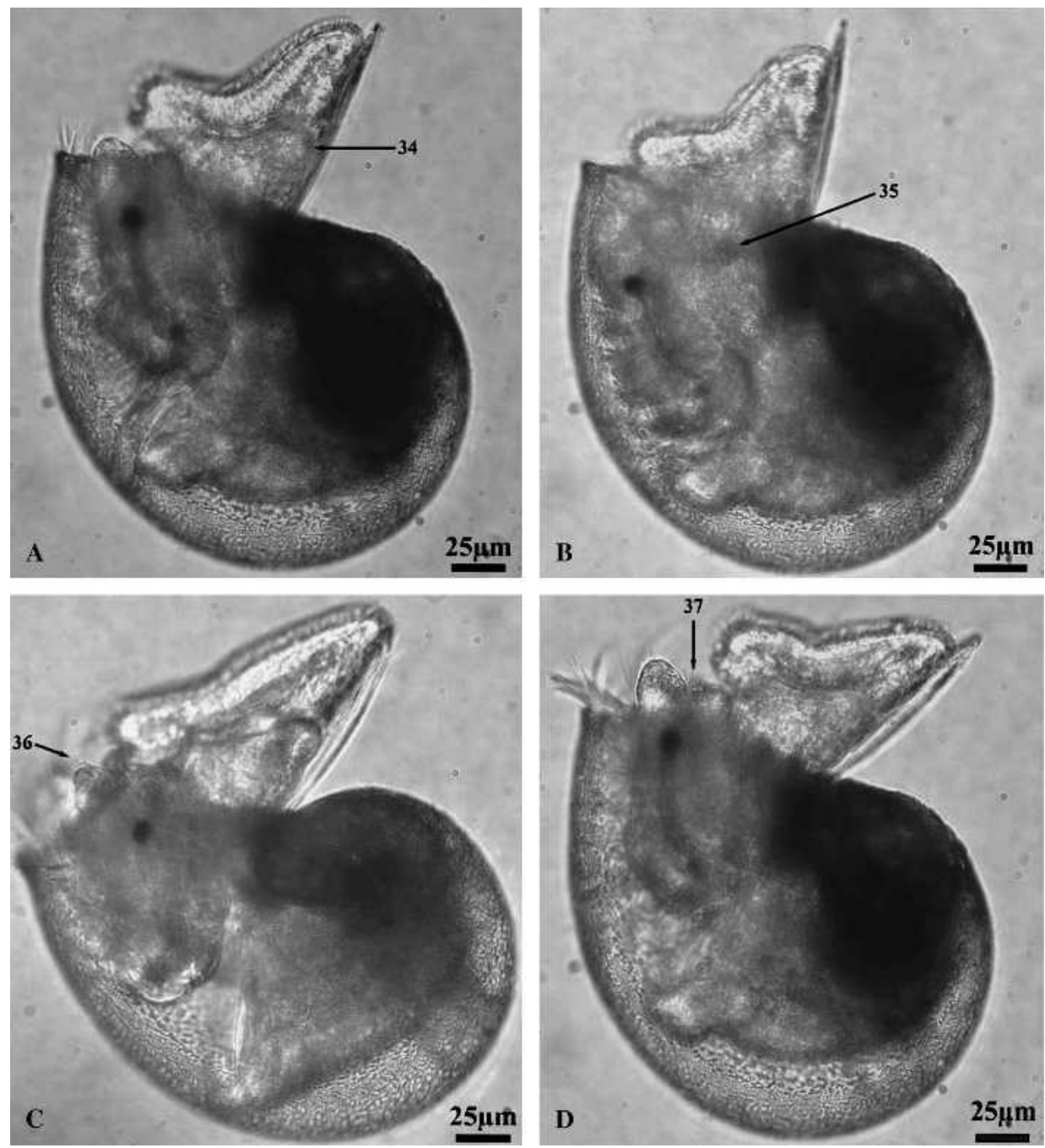

Figure 7. (A) Stage 34, formation of epipodal tentacles. (B) Stage 35, appearance of otolith. (C) Stage 36, appearance of spines on cephalic tentacles, (D) Stage 37, protrusion of snout underneath the velum.

Finally the fact that development rate is only partially described for several abalone species summed to the fact that larval development were studied at different water temperature for different species did not allow the comparison of all reported morphological features between species. Nevertheless the comparison between specific developmental stages such as hatch out and torsion could provide a general tendency about time required for $H$. tuberculata coccinea development
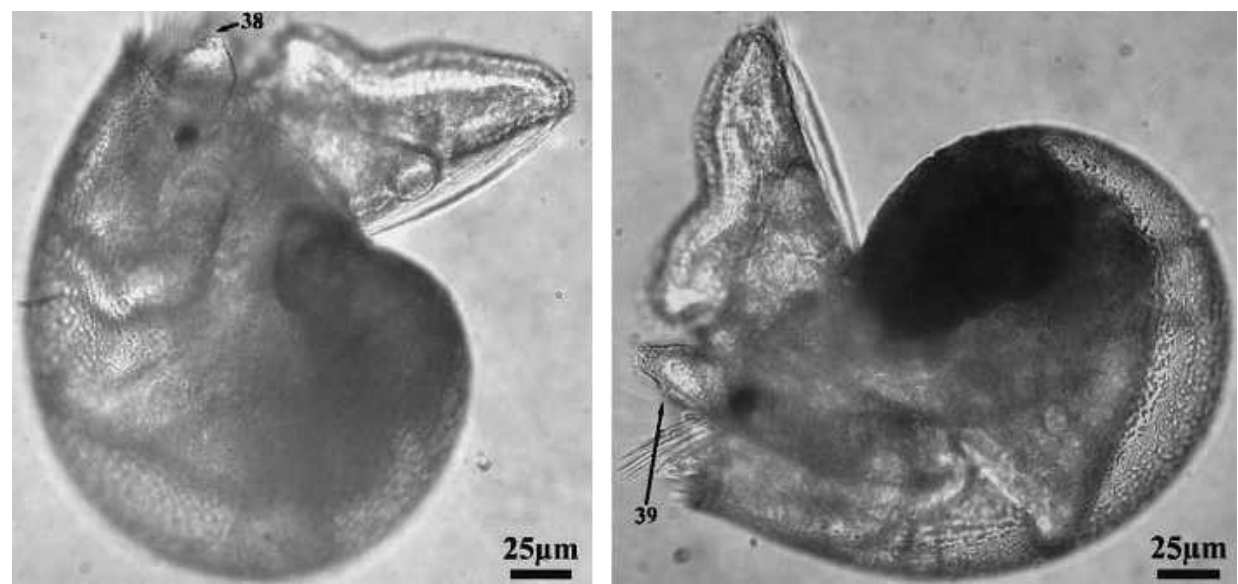

Figure 8. (A) Stage 38, appearance of two tubules on cephalic tentacles. (B) Stage 39, third tubule appearance on cephalic tentacles. 
in comparison with other species. In that case the timing of embryonic and larval development stages of $H$. tuberculata coccinea observed at the reported temperature was more similar to the one of a tropical abalone species like $H$. asinina than to the one of a temperate one. Hahn, (1989) stating that temperature is an important factor in many stages of development such as gonad maturation, spawning, and larval development could help explain the significant differences observed in eggs and larvae characteristics of $H$. tuberculata coccinea between this study and the one of Peña, (1986). Studies of $H$. tuberculata coccinea embryology and larval development at different water temperatures would allow to clarify the importance of this parameter and its consequences on larval production and rearing potential of this subtropical species in comparison with the ones of other abalones species from other regions.

\section{ACKNOWLEDGMENTS}

This study was financed by the Spanish Government within the frame of the National Plan for Development of Marine Cultures (JACUMAR).

\section{LITERATURE CITED}

Ebert, E. E. \& J. L. Houk. 1984. Elements and innovations in the cultivation of red abalone Haliotis rufescens. Aquaculture 39: 375-392.

Hahn, K. O. 1989. Handbook of culture of abalone and other marine gastropods. Boca Raton, Florida: CRC Press. 331 pp.

Harrison, A. J. \& J. F. Grant. 1971. Progress in abalone research. Tasmanian Fish. Res. 5:1-10.

Ino, T. 1952. Biological studies on the propagation of Japanese abalone (Genus Haliotis). Bulletin of the Tokai Regional Fisheries Research Laboratory. pp. 1-102.

Koike, Y. 1978. Biological and ecological studies on the propagation of the omer, Haliotis tuberculata Linnaeus. I. Larval development and growth of juveniles. La Mer. 16:124.

Leighton, D. L. 1972. Laboratory observations on the early growth of the abalone, Haliotis sorenseni, and the effect of temperature on larval development and settling success. Fish. Bull. (Washington DC) 70:373-381.

Leighton, D. L. 1974. The influence of temperature on larval and juvenile growth in three species of southern California abalones. Fish. Bull. (Washington DC) 72:1137.

Morse, D. E., H. Duncan, N. Hooker \& A. N. C. Morse. 1977. Hydrogen peroxide induces spawning in mollusks, with activation of prostaglandin endoperoxide synthetase. Science 196:298300 .

Oba, T. 1964. Studies on the propagation of the abalone Haliotis diversicolor supertexta Lischke. II. On the development. Bull. Jpn. Soc. Sci. Fish 30:809.
Owen, B., L. H. DiSalvo, E. E. Ebert \& E. Fonck. 1984. Culture of the Californian Red abalone Haliotis rufescens Swainason (1822) in Chile. Veliger 27:101.

Peña, J. B. 1984. Egg and larva development of Haliotis discus Reeve (Mollusca, Gastropoda, Prosobranchia). Invest. Pesq. (Barc.) 48: 441-454.

Peña, J. B. 1986. Preliminary study on the induction of artificial spawning in Haliotis coccinea canariensis Nordsieck (1975). Aquaculture 52:35-41.

Sawatpeera, S., E. S. Upatham, M. Kruatrachue, Y. P. Chitramvong, P. Sonchaeng, T. Pumthong \& J. Nugranad. 2001. Larval development in Haliotis asinina Linnaeus. J. Shellfish Res. 20:593-601.

Seki, T. \& H. Kan-no. 1977. Synchronized control of early life in the abalone, Haliotis discus hannai Ino, Haliotidae, Gastropoda. Bull. Tohoku Reg. Fish. Res. Lab. pp. 143- 153.

Toledo, P., R. Haroun, H. Fernández-Palacios, M. S. Izquierdo \& J. Peña. 2000. First culture experiences of Haliotis coccinea canariensis in a biofilter system. J. Shellfish Res. 19:493-541.

Viera, M. P., G. B. R. Courtois de Vicose, H. Fernández-Palacios, J. Roo \& A. Valencia. 2003. Inducción al desove de la almeja canaria Haliotis tuberculata coccinea mediante el método del peróxido de hidrogeno. In: Actas del IX Congreso Nacional de Acuicultura. Junta de Andalucia, Cadiz, pp. 289.

Viera, M. P., J. L. Gómez Pinchetti, G. Courtois de Vicose, A. Bilbao, S. Suárez, R. Haroun \& M. S. Izquierdo. 2005. Suitability of three red macroalgae as a feed for the abalone Haliotis tuberculata coccinea Reeve. Aquaculture 248:75-82. 